\title{
The Effect of Triiodothyronine on Plasma Free Fatty Acid Level during Physical Exercise in Dogs
}

It was found ${ }^{1,2}$ that administration of triiodothyronine $\left(\mathrm{T}_{3}\right)$ to normal rats largely modifies response of white adipose tissue taken from the rats to noradrenaline added to incubation medium. On the other hand, ROSENQUIST ${ }^{3}$ indicated that the lipolytic effect of noradrenaline in vitro is markedly reduced in subcutaneous adipose tissue of hypothyroid human subjects. Since it has been found in this laboratory ${ }^{4}$ that increasing amounts of noradrenaline are released during physical exercice in dogs, the effect of $\mathrm{T}_{3}$ on lipolytic action of endogenous noradrenaline was studied in dogs performing treadmill exercise.

Materials and methods. Experiments were carried out on 5 male, mongrel dogs weighing 18 to $22 \mathrm{~kg}$. Before experiments dogs were deprived of food for $18-20 \mathrm{~h}$, but had free access to water. The dogs performed treadmill exercice of moderate intensity. The slope of the treadmill was $12^{\circ}$ and its speed ranged from 1.4 to $1.8 \mathrm{~m}$ per sec according to the individual capacity of each animal. At first, time of the run until exhaustion was estabilished for each dog. Then, after at least one week interval, the dogs were injected subcutancously with 3,5, 3'-triiodo-Lthyronine (Nutritional Biochemicals Corporation, Ohio) in a single dose $0.1 \mathrm{mg} / \mathrm{kg}$ of body weight 18 to $20 \mathrm{~h}$ before run. Since it has been found that $T_{3}$ markedly reduces time of exercise until exhaustion (from $232 \pm$ [S.E.] $29 \mathrm{~min}$ to $61 \pm 8.0, p<0.001)$ time of the run in control experiments, performed on the same dogs after 2-3 weeks following $T_{3}$ injection, was chosen to be equal to that in $\mathrm{T}_{3}$ treated dogs.

Immediately before exercise, in 30 th $\mathrm{min}$ of exercise, and after its cessation both in control and in $T_{3}$ treated dogs, venous blood samples were taken for determinations of $\mathrm{FFA}^{5}$, glucose ${ }^{6}$, lactate ${ }^{7}$ and noradrenaline (NA) ${ }^{8}$ levels. Rectal temperature was measured immediately before and at the end of exercise, using a termocouple thermometer Ellab, Copenhagen.

Results. The results summarized in the Table show that after $30 \mathrm{~min}$ of exercice an average increase in the plasma

Effect of triiodothyronine $\left(T_{3}\right)$ pretreatment on plasma free fatty acid (FFA) and noradrenaline (NA) levels during exercise in dogs. (Mean \pm S.E.)

\begin{tabular}{|c|c|c|c|c|}
\hline \multirow{2}{*}{$\begin{array}{l}\text { Time of } \\
\text { exercise } \\
\text { (min) }\end{array}$} & \multicolumn{2}{|l|}{ Controls } & \multicolumn{2}{|c|}{$\mathrm{T}_{3}$-treated dogs } \\
\hline & $\begin{array}{l}\mathrm{FFA} \\
(\mu \mathrm{Eq} / 1)\end{array}$ & $\begin{array}{l}\text { NA } \\
(\mu g / 1)\end{array}$ & $\begin{array}{l}\text { FFA } \\
(\mu \mathrm{Eq} / \mathrm{l})\end{array}$ & $\begin{array}{l}\text { NA } \\
(\mu g / 1)\end{array}$ \\
\hline 0 & $379 \pm 24$ & $0.94 \pm 0.069$ & $469 \pm 53$ & $1.03 \pm 0.085$ \\
\hline 30 & $435 \pm 20$ & $1.33 \pm 0.055$ & $1426 \pm 171$ & $1.54 \pm 0.060$ \\
\hline 60 & $447 \pm 21$ & $1.46 \pm 0.017$ & $1156 \pm 176$ & $1.79 \pm 0.11$ \\
\hline
\end{tabular}

FFA concentration was $55.5 \pm$ (S.E.) $4.0 \mu \mathrm{Eq} / 1$ in control experiments, while in $\mathrm{T}_{3}$ experiments it amounted to $958 \pm 43 \mu \mathrm{Eq} / 1(p<0.001)$. At the point of exhaustion, the plasma level of FFA in $\mathbf{T}_{\mathbf{3}}$-treated dogs was lower than after $30 \mathrm{~min}$ of exercise, but the difference between control and $T_{3}$-treated dogs was still very strongly expressed $(p<0.001)$.

NA blood level increased gradually during exercise both in control and in $T_{3}$ experiments, as described before ${ }^{4}$. There were no significant changes between control and $\mathrm{T}_{3}$-treated dogs in blood glucose and lactate levels during exercise. Rectal temperature of control and $\mathrm{T}_{3}$-treated, resting dogs was similar ( $39 \pm$ [S.E.] 0.15 and $39^{\circ} \pm 0.2^{\circ} \mathrm{C}$, respectively) immediately before exercise. However, at the end of the run it was on average $0.9^{\circ} \mathrm{C}$ higher in $\mathbf{T}_{3}$ treated dogs than in controls $(p<0.05)$.

Discussion. The data presented here indicate that $T_{3}$ pretreatment markedly increases plasma free fatty acid level during physical exercise in dogs.

It is known that noradrenaline is the main lipolytic factor acting during prolonged physical exercise in dogs ${ }^{4}$, so it seems likely that $T_{3}$ increases adipokinetic action of the hormone. A possibility that the much higher level of free fatty acids in plasma of $\mathrm{T}_{3}$-treated dogs is a consequence of disturbances in realization of FFA, cannot be completely excluded, although similar degree of carbohydrate utilization in exercising dogs (to be published) speaks against it.

The results presented confirm those obtained in vitro ${ }^{1,2}$. Thus, it seems likely that the explanation of the phenomenon given by CADWELL and $\mathrm{FAIN}^{\mathrm{I}}$ that $T_{3}$ markedly increases maximal accumulation of cyclic AMP in response to NA is also true in vivo, in physiological situation of physical exercise. On the other hand, the present results are contrary to those obtained by SvEDMYR ${ }^{9}$ who failed to demonstrate potentialization of FFA-mobilizing effect of NA by triiodothyronine in human subjects or thyroxine in rabbits.

It is supposed that impairment of working capacity in $\mathrm{T}_{3}$-treated dogs may be due to the marked increase of deep body temperature found in these dogs during exercise.

Résumé. La triiodothyronine $\left(\mathrm{T}_{3}\right)$ administrée aux chiens en une seule dose de $0.1 \mathrm{mg} / \mathrm{kg}, 18-20 \mathrm{~h}$ avant l'effort physique fait augmenter sensiblement le niveau des acides gras libres et la température rectale pendant l'exercice, ce qui raccourcit en même temps la durée de l'effort.

Hanna Kaciuba-Uścilko and Zofia Brzezinska ${ }^{10}$

Laboratory of Applied Physiology, Medical Research

Centre, Polish Academy of Sciences,

Jazgarzewska 1, 00-730 Warszawa (Poland), 16 July 1973.
1 ANne CADWEll and J. N. Fain, Endocrinology 89, 1195 (1971).

2 J. N. Fain and Judith W. Rosenthat, Endocrinology 89, 1205 (1971).

3 U. Rosenouist, Acta med. scand. 192, 361 (1972).

4 Zofia Brzezinska, W. Kowalski and K. NazAr, Acta physiol. pol. 24, 339 (1973).

${ }^{5}$ F. Mosinger, J. Lipid Res. 6, 157 (1965).
${ }^{6}$ E. J. KING, Micro-Analysis, in: Medical Biochemistry, (J. A. Churchill, London 1957).

7 S. Srröm, Acta physiol. scand. 77, 440 (1949).

8 A. H. Anton and D. F. SAYRe, J. Pharmac. exp. Ther. 138,360 (1962).

${ }^{9}$ N. Svedmyr, Acta physiol. scand. 68, suppl., 274 (1966).

10 The skilled technical assistance of Mrs. WANDA RaDzISzEwSKA and Mr. Ryszard SzOStak is gratefully acknowledged. 